\title{
Baseline levels of biomarkers of oxidative damage in Odontesthes nigricans (Pisces, Atherinopsidae) from two coastal areas of the Beagle Channel, Argentina
}

\author{
Niveles basales de biomarcadores de daño oxidativo en Odontesthes nigricans (Pisces, \\ Atherinopsidae) en dos áreas costeras del Canal Beagle, Argentina
}

\author{
MARÍA E. LATTUCA ${ }^{1}$, ANALÍA F. PÉREZ ${ }^{2}$, ERICA GIARRATANO ${ }^{3}$ \& GABRIELA MALANGA4, \\ ${ }^{1}$ Laboratorio de Ecología, Fisiología y Evolución, Centro Austral de Investigaciones Científicas (CADIC -CONICET), Bernardo \\ Houssay 200 (V9410BFD) Ushuaia, Tierra del Fuego, Argentina \\ ${ }^{2}$ Laboratorio de Invertebrados Marinos, Centro de Estudios Biomédicos, Biotecnológicos, Ambientales y Diagnósticos \\ (CEBBAD), Universidad Maimónides, Hidalgo 775, (C1405BCK), Buenos Aires, Argentina \\ ${ }^{3}$ Centro Nacional Patagónico (CENPAT - CONICET), Blvd. Brown 2915, (U9120ACD) Puerto Madryn, Chubut, Argentina \\ ${ }^{4}$ Físicoquímica IBIMOL, FFyB, UBA, Junín 956, (C1113AAD) Buenos Aires, Argentina \\ ${ }^{*}$ Corresponding author: gmalanga@ffyb.uba.ar
}

\begin{abstract}
We assessed several biomarkers of oxidative damage on silversides Odontesthes nigricans from Varela and Golondrina bays, located on the North shore of the Beagle Channel (Tierra del Fuego, Argentina) and we tried to relate those responses to environmental data. Varela bay is visited mostly by local fishermen and tourism during the spring-summer season; on the other hand Golondrina bay is a low urban impacted area, despite the population's growth around it. We employed the condition factor as general biomarker of fish health and quantified biomarkers of oxidative damage in gills and liver. Fishes from Golondrina bay showed a better condition as compared to those from Varela bay. The activity of enzymatic antioxidants and the content of non-enzymatic antioxidants were lower in gills than in the liver, independently of the sampling site. No significant differences were found between sites in the gills. However, an increase in catalase and superoxide dismutase activities and a decrease in GSH/GSSG ratio were observed in the liver of fishes from Varela bay, possibly being due to higher levels of environmental natural stresses, mainly metals in sediments. This study indicates an organ-dependent response and establishes different baseline levels of biochemical parameters for each bay that could be considered as values of normal homeostasis for wild silversides.
\end{abstract}

Key words: Beagle Channel, Odontesthes nigricans, oxidative stress biomarkers.

\section{RESUMEN}

Se evaluaron diversos biomarcadores de daño oxidativo en el pejerrey Odontesthes nigricans proveniente de las bahías Varela y Golondrina, ubicadas sobre la costa norte del Canal Beagle (Tierra del Fuego, Argentina), y se trataron de relacionar las respuestas observadas a los datos ambientales. Bahía Varela es principalmente visitada por pescadores locales y turistas durante la temporada de primavera-verano, por otro lado Bahía Golondrina es un área de escaso impacto humano, a pesar del crecimiento poblacional registrado en sus inmediaciones. Los peces de Bahía Golondrina mostraron una mejor condición en comparación a aquéllos provenientes de Bahía Varela. La actividad de los antioxidantes enzimáticos y el contenido de los antioxidantes no enzimáticos fueron más bajos en las branquias que en el hígado, independientemente del sitio de muestreo. No se encontraron diferencias significativas en las branquias entre sitios de muestreo. Sin embargo, se observó un aumento en la actividad de la catalasa y la superóxido dismutasa y una disminución en la relación GSH/GSSG en el hígado de los peces de Bahía Varela, posiblemente debido a mayores niveles de estresores ambientales naturales, principalmente metales en los sedimentos. Este estudio indica una respuesta órgano-dependiente y establece diferentes niveles basales de parámetros bioquímicos para cada bahía que pueden ser considerados como valores normales de homeostasis de pejerreyes salvajes.

Palabras clave: Biomarcadores de estrés oxidativo, Canal Beagle, Odontesthes nigricans.

\section{INTRODUCTION}

Aquatic ecosystems are the main recipients of pollutants, which, over time, can cause serious consequences for biota that may not become apparent until changes occur at the population or ecosystem level, a point at which it may be too late to take 
effective countermeasures (Linde-Arias et al. 2008). The need to detect and assess the impact of pollutants, particularly at sublethal concentrations, on environmental quality has led to measure a range of biological responses in different species (Alves de Almeida et al. 2007, Viarengo et al. 2007, Vlahogianni \& Valavanidis 2007, Ahmad et al. 2008). The use of biological responses to different environmental conditions, defined as biomarkers, has become a useful tool in environmental quality evaluation and risk assessment. Among the numerous ecotoxicological biomarkers, those based on responses at the molecular and cellular levels represent the earliest signals of environmental disturbance and they are commonly used for biomonitoring (Moore et al. 2004, Viarengo et al. 2007). Measuring the same biomarker in different locations simultaneously gives us information about the pollution status of the region and provides a better comprehension of the mechanisms of response of the organisms to pollutants (Giarratano et al. 2010). Although biomarkers can be helpful for gaining insight regarding the mechanisms causing observed effects of chemicals on whole-organism performance and may, in some cases, provide useful indicators of exposure, individual biomarker responses should not be expected to provide useful predictions of relevant ecological effects and probably not even predictions of whole-organism effects (Forbes et al. 2006).

Fishes are generally considered feasible organisms for pollution monitoring because they can be found virtually everywhere in the aquatic environment and they play a major ecological role in aquatic food-webs because of their function as carriers of energy from lower to higher trophic levels (Beyer 1996). The use of fish in environmental monitoring has become increasingly important in recent years in the investigation of natural variability, as well as anthropogenic substances, many of which function as prooxidants, accumulating in aquatic environments (Almroth et al. 2008). Prooxidants can induce morphological and physiological alterations in fish tissues (Bainy et al. 1996, Varanka et al. 2001), such as oxidative damage to lipids (lipid peroxidation). To counteract tissue damage, fishes as well as other organisms have developed different enzymatic and non-enzymatic defensive mechanisms to protect themselves against reactive oxygen species (ROS) production
(Winston \& Di Giulio 1991). The enzymes superoxide dismutase (SOD) and catalase (CAT) are among the enzymatic antioxidants. Superoxide anions are dismutated by SOD to hydrogen peroxide $\left(\mathrm{H}_{2} \mathrm{O}_{2}\right)$, which are subsequently detoxified by CAT present in peroxisomes. Numerous non-enzymatic low-molecular-weight antioxidants, such as ascorbate, $\beta$-carotene, $\alpha$-tocopherol and GSH, have also been described (Stegeman et al. 1992, Lopez-Torres et al. 1993). Ascorbate is an important water-soluble antioxidant which is known to directly scavenge ROS (Halliwell \& Gutteridge 1999), acting also as a crucial micronutrient and performing various vital physiological functions such as collagen synthesis and connective tissue formation (Wilson \& Poe 1973). The $\alpha$-tocopherol and $\beta$-carotene are lipid-soluble antioxidants which play a major role in protecting membranes from lipid peroxidation (van der Oost et al. 2003). Glutatione reduced (GSH) is the most abundant cellular thiol and it is involved in several metabolic processes (DeLeve \& Kaplowitz 1991), playing a central role in the detoxification of ROS. As consequence of oxidizing conditions, two molecules of GSH are linked by a disulfide bond to comprise one molecule of oxidized glutathione (GSSG). Both total GSH and the ratio of GSH content/ GSSG content can be used as biomarkers for oxidative stress (Koivula \& Eeva 2010). Swiergosz-Kowalewska et al. (2006) concluded that the GSH content/GSSG content ratio may be the best and the most sensitive indicator of metal toxicity for animals living in chronically contaminated environments.

The silverside Odontesthes nigricans (Richardson, 1848) is a native fish species in Tierra del Fuego (southernmost limit of its distribution) that can be found by following the tides in the coastal waters and estuaries of the Atlantic Ocean and Beagle Channel. It is a species of a regional socioeconomic relevance due to the sport and artisanal fishing developed upon it. The oxidative metabolism of $O$. nigricans was previously characterized by Lattuca et al. (2009). O. nigricans was also chosen because another species of the same genus, Odontesthes bonariensis (Valenciennes, 1835), has been recently promoted as test species in a standardized acute toxicity test method in Argentina (IRAM 2007), due 
to its relatively high sensitivity to metals (Carriquiriborde \& Ronco 2002, 2008).

The aim of this work was to determine baseline levels of a condition factor, as general biomarker of fish health, and of several biomarkers of oxidative damage, such as lipid radical content, enzymatic antioxidants (activities of superoxide dismutase and catalase), non-enzymatic antioxidants ( $\alpha$-tocopherol, $\beta$-carotene, ascorbate and glutathione contents) and general indexes of oxidative stress (ascorbyl/ascorbate and reduced glutathione/oxidized glutathione ratios) in gills and liver of $O$. nigricans from two coastal areas within Beagle Channel. Present study represents the first comprehensive investigation that set oxidative stress responses in fishes from clean coastal waters of the Beagle Channel, essential information for a proper interpretation of future ecotoxicological data and environmental monitoring programs in this austral region.

\section{METHODS}

Authors wish to declare that this study was conducted in accordance with Guidelines on the care and use of animals for scientific purposes established by the National Advisory Committee for Laboratory Animal Research (2004).

\section{Sampling sites}

Fishes were collected in spring (October) of 2007 at Golondrina and Varela bays, located on the North coast of the Beagle Channel (Tierra del Fuego, Argentina) (Fig. 1). Golondrina bay $\left(54^{\circ} 50^{\prime} \mathrm{S}, 68^{\circ} 21^{\prime} \mathrm{W}\right)$ is located

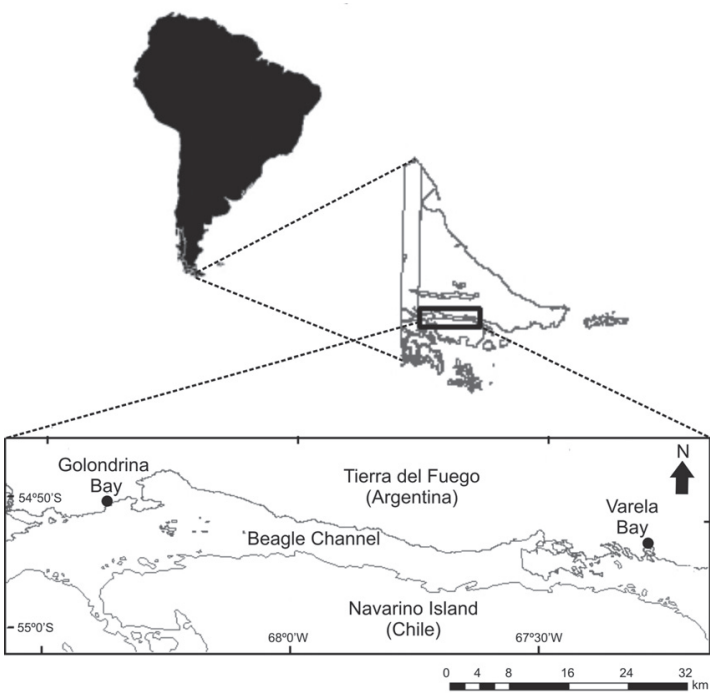

Fig. 1: Location of sampling sites.

Localización de los sitios de muestreo. near Ushuaia city and has been recently considered by Duarte et al. (2011) as low urban impacted area, despite the population's growth around it. Varela bay $\left(54^{\circ} 52^{\prime} \mathrm{S}\right.$, $67^{\circ} 16^{\prime} \mathrm{W}$ ), located $70 \mathrm{~km}$ East from Golondrina bay, is considered a low impacted area, being mostly visited by local fishermen and tourists during the spring-summer season. The nearest place where environmental data has been reported is Brown bay ( $54^{\circ} 52^{\prime} \mathrm{S}, 67^{\circ} 34^{\prime} \mathrm{W}$ ) (Giarratano \& Amin 2010), $20 \mathrm{~km}$ west of Varela bay. At that place, only a commercial production of mussels is being developed since 2001 (Hernando et al. 20081).

\section{Fish collection and processing}

Ten adult specimens (185 - $210 \mathrm{~mm}$ total length, TL; 35 - 55 g body weight, BW) were collected at both sampling sites by means of a seine net (60 m long, 1.5 $\mathrm{m}$ high and $12 \mathrm{~mm}$ stretched mesh) covering ca. 200 $\mathrm{m}$, from $1 \mathrm{~m}$ depth to the shallower littoral zone. Fishes were carried alive to the laboratory into $100 \mathrm{~L}$ tanks containing aerated seawater. In order to minimize stress generated during capture and transportation, fishes were held in the laboratory during $24 \mathrm{~h}$ under similar field conditions $\left(8 \pm 0.5^{\circ} \mathrm{C}\right.$; light:dark photoperiod of $14: 10$ h). According to Cazenave et al. (2009) and Nahrgang et al. (2010), twenty-four hours after catch fishes from both sampling sites were sacrificed by a blow to the head. TL of each individual was measured with a digital calliper $( \pm 0.1 \mathrm{~mm})$ and $\mathrm{BW}$ was recorded to the nearest 0.01 $\mathrm{g}$. Condition of individual fish was indexed by Fulton's condition factor calculated as $\mathrm{K}=\left[\mathrm{BW} \times\left[\mathrm{TL}^{3}\right]^{-1}\right] \times 100$ (Bagenal \& Tesch 1978). Considering that Lattuca et al. (2009) found no significant differences between sexes in oxidative stress biomarkers for O. nigricans, sex differentiation was not made in this sudy. Gills and liver were dissected, weighed $\left( \pm 10^{-5} \mathrm{~g}\right)$ and stored at $-80{ }^{\circ} \mathrm{C}$ for 2 weeks, until analysis.

\section{Environmental physicochemical parameters}

At each sampling site, surface water temperature, $\mathrm{pH}$, conductivity and dissolved oxygen were recorded once in situ by means of an HORIBA U-10 multiparameter device. Concentration of chlorophyll-a was measured according to Holm-Hansen \& Riemann (1978) using a Sequoia Turner (model 450) fluorometer.

\section{Biochemical measurements}

Quantification of lipid radicals by electron paramagnetic resonance (EPR)-spin trapping

Lipid radicals were detected by a spin trapping technique using N-t-butyl- $\alpha$-phenyl nitrone (PBN). A 40 mM PBN stock solution was prepared in dimethyl sulfoxide (DMSO) immediately prior to use. The homogenates were prepared by adding DMSO-PBN (stock solution) in frozen tissue (10 to $20 \mathrm{mg}$ ). EPR spectra were obtained at room temperature using a Bruker spectrometer ECS 106 , operating at $9.81 \mathrm{GHz}$ with $50 \mathrm{kHz}$ modulation frequency. EPR instrument settings for the spin trapping experiments were: microwave power, $20 \mathrm{~mW}$;

1 HERNANDO M, E TORRES, N SAN ROMÁN \& M HOFFMEYER (2008). Informe Final: Monitoreo planctónico y ambiental para el desarrollo sustentable del cultivo comercial de mejillón (Mytilus edulis chilensis) en la zona de Almanza, Canal Beagle (Tierra del Fuego). 
modulation amplitude, 1.194G; time constant, 81.92 ms; scan numbers, 5 ; center fields, $3480 \mathrm{G}$; modulation frequency, $50 \mathrm{kHz}$; and receiver gain, 2.104 (Lai et al. 1986). Quantification was performed according to Kotake et al. (1996).

\section{Content of lipid soluble antioxidants}

The contents of $\alpha$-tocopherol $(\alpha-\mathrm{TH})$ and $\beta$-carotene in homogenates from gills and liver were quantified by reverse-phase HPLC with electrochemical detection using a Bioanalytical Systems LC-4C amperometric detector with a glassy carbon working electrode at an applied oxidation potential of $0.6 \mathrm{~V}$. Samples were extracted with $1 \mathrm{~mL}$ of ethanol and $4 \mathrm{~mL}$ of hexane. After centrifugation at $600 \mathrm{~g}$ for $10 \mathrm{~min}$, the hexane phase was removed and evaporated to dryness under $\mathrm{N}_{2}$. Extracts were dissolved in methanol/ethanol (1:1) and injected for HPLC analysis (Desai 1984). The equipment employed was a Perkin Elmer 250 LC bomb, a fixed phase: Supelcosil LC- 8 column ( $3 \mu \mathrm{m}$ size particle) $4.6 \mathrm{x}$ $330 \mathrm{~mm}$, a mobile phase: $20 \mathrm{mM}$ lithium perchlorate in methanol/water 99:1 (v/v), and a $1 \mathrm{~mL} \mathrm{~min}^{-1}$ flow. D, L- $\alpha-$ tocopherol (Sigma) and $\beta$-carotene (Sigma) were used as standards (Fig. 2).

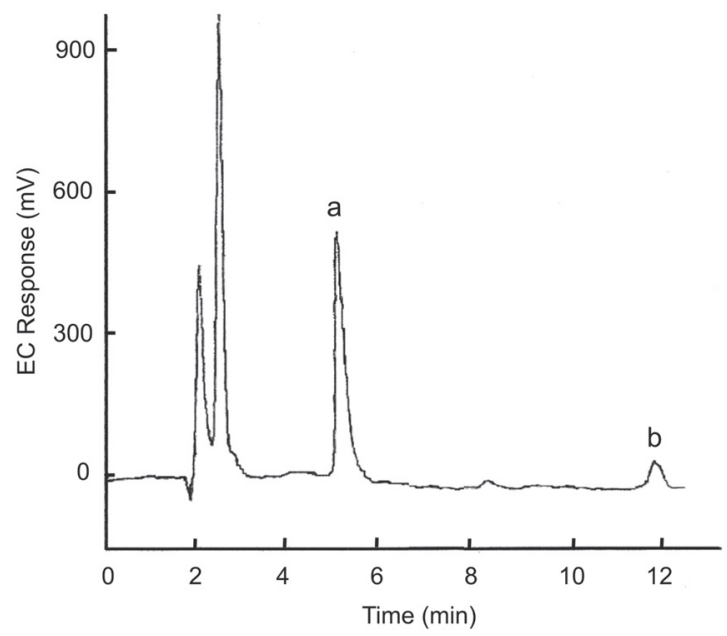

Fig. 2: Determination of lipid soluble antioxidants content by the high-performance liquid chromatography (HPLC) method. Elution time for the tested standards were: $5.5 \mathrm{~min}$ for $\alpha$-TH (a) and $11.8 \mathrm{~min}$ for $\beta$-carotene (b).

Determinación del contenido de antioxidantes liposolubles por cromatografía líquida de alta resolución (HPLC). Los tiempos de elución para los estándares fueron para: $\alpha$-TH 5.5 $\min (\mathrm{a})$ y $\beta$-caroteno $11.8 \mathrm{~min}$ (b).

\section{Enzymatic assays}

Homogenates from gills and liver were prepared in $50 \mathrm{mM}$ potassium phosphate $120 \mathrm{mM} \mathrm{KCl}(\mathrm{pH}=7.4)$. Catalase activity was assayed spectrophotometrically by the decomposition of $\mathrm{H}_{2} \mathrm{O}_{2}$ at $\lambda=240 \mathrm{~nm}$ in a reaction mixture consisting of $50 \mathrm{mM}$ potassium phosphate buffer ( $\mathrm{pH} 7.0$ ) containing 1\% Triton-X100, 1:9 (w/v) and $12.5 \mathrm{mM} \mathrm{H}_{2} \mathrm{O}_{2}$ (Aebi 1984). Total superoxide dismutase activity was determined by the epinephrine method (Misra \& Fridovich 1972), based on the capacity of SOD to inhibit the autooxidation of epinephrine to adrenochrome at $480 \mathrm{~nm}$.

Ascorbyl radical content (A)

A • measurements were done using a Bruker ECS 106 spectrometer. Gills and liver homogenates were prepared by adding $100-150 \mathrm{mg}$ of tissue to pure DMSO (1:3) (w/v). The spectra were scanned at room temperature under the following conditions: $50 \mathrm{kHz}$ field modulation, microwave power $20 \mathrm{~mW}$, modulation amplitude $1 \mathrm{G}$, time constant $655 \mathrm{~ms}$, receiver gain 1 x $10^{5}$, microwave frequency $9.81 \mathrm{GHz}$, and scan rate 0.18 G/s (Giulivi \& Cadenas 1993). The amount of spin adduct was calibrated using an aqueous solution of TEMPOL, introduced into the same cell used for spin trapping. EPR spectra of spin adduct and TEMPOL solutions were recorded at exactly the same spectrometer settings. The first-derivative EPR spectra were doubly integrated to obtain the area intensity, and then the concentration of spin adduct was calculated using the ratio of these areas. Quantification was performed according to Kotake et al. (1996).

Ascorbate content ( $\left.\mathrm{AH}^{-}\right)$

The content of $\mathrm{AH}^{-}$was measured by reverse-phase HPLC with electrochemical detection using a LC-4C amperometric detector with a carbon working electrode at an applied oxidation potential of $0.6 \mathrm{~V}$. The samples were homogenized in metaphosphoric acid (10 \%, w/v) according to Kutnink et al. (1987). A Supelcosil LC-18 column was stabilized with metaphosphoric acid $(0.8 \%$, $\mathrm{w} / \mathrm{v}$ ) and a freshly prepared solution of ascorbic acid in metaphosphoric acid $(10 \%, \mathrm{w} / \mathrm{v})\left(1 \mu \mathrm{g} \mathrm{mL}^{-1}\right)$ was used as standard.

Reduced glutathione (GSH) and oxidized glutathione (GSSG) contents

In order to assess GSH and GSSG contents, homogenates from gills and liver were prepared in $1.0 \mathrm{M} \mathrm{HClO}_{4}$ and $2 \mathrm{mM} \mathrm{EDTA} \mathrm{(1:5)} \mathrm{(w/v).} \mathrm{After}$ centrifugation at $29000 \mathrm{~g}$ and $4{ }^{\circ} \mathrm{C}$ for $20 \mathrm{~min}$, the lipid layer was discarded. Meanwhile, the protein free supernatant was filtered with a $0.22 \mu \mathrm{m}$ nylon membrane and immediately analyzed. The contents of GSH and GSSG were quantified by reverse-phase HPLC analysis (isocratic modality) following the method described by Rodriguez-Ariza et al. (1994). The equipment employed was: a Perkin Elmer 250 LC bomb, a fixed phase: Supelcosil LC-18 column (5 $\mu \mathrm{m}$ size particle) 4.6 x 250 $\mathrm{mm}$, a mobile phase: $20 \mathrm{mM} \mathrm{NaH} \mathrm{PO}_{4}, \mathrm{pH} \mathrm{2.7}$, and an electrochemical detector: ESA Coulochem II with an analytical cell ESA 5011, at an applied potential of $+0.45 \mathrm{~V}$ and $0.80 \mathrm{~V}$ and a $1.2 \mathrm{~mL} \mathrm{~min}^{-1}$ flow. Quantification of GSH and GSSG was performed through a standard curve with a linear relationship between 5-200 ng GSH or GSSG, respectively.

\section{Statistical analyses}

Data in the text and tables are expressed as mean $\pm \mathrm{SE}$ for three replicates of each of the five individuals from each sampling site. Statistical test of Mann-Whitney was carried out using GraphPad InStat, version 3.01. When the two-tailed $\mathrm{P}$ value was $<0.05$, it was considered significant. 
TABLE 1

Physicochemical parameters of water from the different sampling sites. Data are expressed as mean \pm S.E. for three replicates of each of the five individuals from each sampling site.

Parámetros fisicoquímicos del agua de los distintos sitios de muestreo. Los datos están expresados como la media \pm EE de tres réplicas para cada uno de los cinco individuos de cada sitio de muestreo.

\begin{tabular}{lcc}
\hline & Varela bay & Golondrina bay \\
\hline $\mathrm{pH}$ & $7.9 \pm 0.3$ & $8.2 \pm 0.3$ \\
Conductivity $\left(\mathrm{mS} \mathrm{cm}^{-1}\right)$ & $40 \pm 3$ & $46 \pm 3$ \\
Dissolved oxygen $\left(\mathrm{mg} \mathrm{L}^{-1}\right)$ & $9.2 \pm 0.8$ & $10.2 \pm 0.2$ \\
Temperature $\left({ }^{\circ} \mathrm{C}\right)$ & $7.7 \pm 0.4$ & $8.4 \pm 0.6$ \\
Salinity $(\mathrm{ppm})$ & $28.1 \pm 0.9$ & $25 \pm 2$ \\
Chlorophyll-a $\left(\mathrm{g} \mathrm{L} \mathrm{L}^{-1}\right)$ & $0.29 \pm 0.07$ & $0.22 \pm 0.07$ \\
\hline
\end{tabular}

\section{RESULTS}

Physicochemical parameters of seawater were similar in both bays (Table 1 ).

The condition of the whole body was used as an initial screening biomarker, measured through $\mathrm{K}$ condition factor. Differences in $\mathrm{K}$ values were observed between sampling sites where fishes from Golondrina bay had significant higher $\mathrm{K}$ factor than those from Varela bay (Fig. 3, Mann-Whitney test; $\mathrm{U}=$ $2.000 ; \mathrm{n}=10 ; \mathrm{P}=0.032$ )

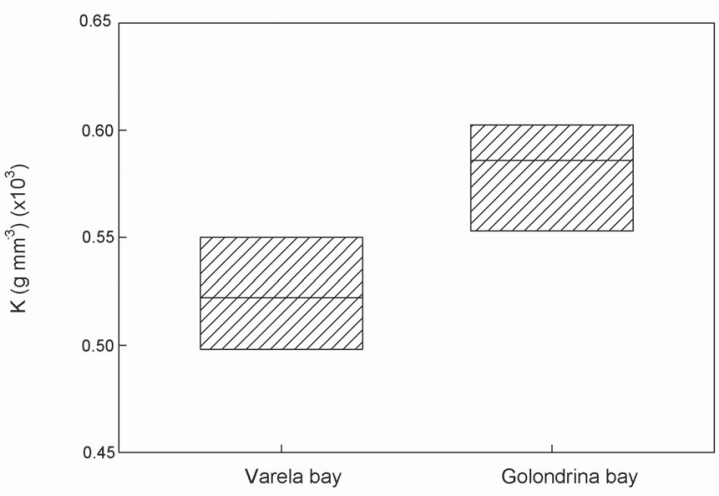

Fig. 3: Condition factor $(\mathrm{K})$ of ten $O$. nigricans collected from different sampling sites. Median, quartiles and 5 th and 95 th percentiles are indicated.

Factor de condición (K) de diez O. nigricans capturados en los distintos sitios de muestreo. Se indican mediana, cuartiles y percentilos $5^{\circ}$ y $95^{\circ}$.

Oxidative damage to lipid in the gills and the liver of silversides was estimated in the present study as lipid radical content assessed by EPR. Lipid radicals in both organs combined with the spin trap PBN resulted in adducts that gave a characteristic EPR spectrum with hyperfine coupling constants of $\mathrm{a}_{\mathrm{N}}=15.56 \mathrm{G}$ and $\mathrm{a}_{\mathrm{H}}=2.79 \mathrm{G}$, in concordance with computer spectral simulated signals obtained using the overall mentioned parameters. PBN itself was examined and no PBN spin adduct was observed. Spectra showed a signal from a second radical species with hyperfine coupling constants $\mathrm{a}_{\mathrm{N}}=15.91$ and $\mathrm{a}_{\mathrm{H}}=3.19$, corresponding to a carbon-centered endogenous radical of unknown origin. However, even though the signal was not fully identified, it may reflect the formation of a PBN$\mathrm{CH}_{3}$ adduct. Since hydroxyl radical formation in vivo may occur under these experimental conditions, its reaction with DMSO could result in the generation of methyl radical that could be trapped by PBN, forming the adduct PBN- $\mathrm{CH}_{3}$ detected by EPR (Mason et al. 1994, Dikolova et al. 2001). Neither lipid radical content in gills (Golondrina bay: $3.7 \pm 0.7 \mathrm{pmol} \mathrm{mg}^{-1} \mathrm{FW}$; Varela

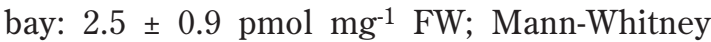
test; $\mathrm{U}=7.000 ; \mathrm{n}=10 ; \mathrm{P}=0.309$ ) nor in the liver of $O$. nigricans (Golondrina bay: $0.8 \pm 0.2$ pmol $\mathrm{mg}^{-1} \mathrm{FW}$; Varela bay: $0.99 \pm 0.08$ pmol $\mathrm{mg}^{-1} \mathrm{FW}$; Mann-Whitney test; $\mathrm{U}=7.000 ; \mathrm{n}=$ $10 ; \mathrm{P}=0.309$ ) showed significant differences between sampling sites. When comparing the lipid radical content between organs of fishes from the same sampling site, only those from Golondrina bay showed significant differences, with higher values in gills (Mann-Whitney test; $\mathrm{U}=0.000 ; \mathrm{n}=10 ; \mathrm{P}=0.008)$. 
The content of non-enzymatic antioxidants and the activity of the antioxidant enzymes were also evaluated in both organs assayed. Independently of the sampling site, all of them were lower in gills than in the liver.

Regarding the non-enzymatic lipid antioxidants, the contents of $\alpha$-tocopherol (Mann-Whitney test; $\mathrm{U}=2.000 ; \mathrm{n}=10 ; \mathrm{P}=$ 0.063 ) and $\beta$-carotene (Mann-Whitney test; $\mathrm{U}=3.000 ; \mathrm{n}=10 ; \mathrm{P}=0.25)$ in the gills did not showed significant differences between sampling sites (Table 2). In the liver (Table 2), the content of $\alpha$-tocopherol was significantly higher in fishes from Varela bay than in those from Golondrina bay (Mann-Whitney test; $\mathrm{U}=$ $0.000 ; \mathrm{n}=10 ; \mathrm{P}=0.029$ ), whereas the content of $\beta$-carotene did not show significant differences between sampling sites (Mann-Whitney test; $\mathrm{U}=8.000 ; \mathrm{n}=10 ; \mathrm{P}=0.421)$. The contents of both non-enzymatic lipid antioxidants were significantly higher in the liver than in the gills of fishes from the same sampling site ( $\alpha$-tocopherol for Varela bay: Mann-Whitney test; $\mathrm{U}=0.000 ; \mathrm{n}=10 ; \mathrm{P}=0.016 ; \alpha$-tocopherol for Golondrina bay: Mann-Whitney test; $\mathrm{U}=$ $0.000 ; \mathrm{n}=10 ; \mathrm{P}=0.008 ; \beta$-carotene for Varela bay: Mann-Whitney test; $\mathrm{U}=0.000 ; \mathrm{n}=10 ; \mathrm{P}=$ 0.036 and $\beta$-carotene for Golondrina bay: MannWhitney test; $\mathrm{U}=1.000 ; \mathrm{n}=10 ; \mathrm{P}=0.015)$.

A high activity of CAT was also registered in the liver, being $53 \%$ higher in fishes from Varela bay than in those from Golondrina bay (Table 2, Mann-Whitney test, $\mathrm{U}=27.000 ; \mathrm{n}=$ $10 ; \mathrm{P}=0.050$ ). The activity of CAT could not be determined in the gills due to the lack of sample. The activity of SOD in the gills did not differ significantly between sampling sites (Table 2, Mann-Whitney test; $\mathrm{U}=10.000 ; \mathrm{n}$ $=10 ; \mathrm{P}=0.429$ ), but it did in the liver, being $44 \%$ higher in Varela bay than in Golondrina bay (Table 2, Mann-Whitney test; $\mathrm{U}=0.000$; $\mathrm{n}=10 ; \mathrm{P}=0.009)$. No significant differences were observed in the activity of SOD between organs at each sampling site (Table 2, Varela bay: Mann-Whitney test; $\mathrm{U}=14.000 ; \mathrm{n}=10 ; \mathrm{P}=$ 0.931; Golondrina bay: Mann-Whitney test; $\mathrm{U}=$ 10.000; $\mathrm{n}=10 ; \mathrm{P}=0.240$ ).

Typical EPR spectra of $A$ in the gills and in the liver of fishes collected at the two sampling sites were observed with the characteristic two lines at $\mathrm{g}=2.005$ and $\mathrm{a}_{\mathrm{H}}=1.8 \mathrm{G}$, in accordance to computer spectral simulated signals obtained with the parameters given in the Material and Methods section. Neither the content of $\mathrm{A}$. (Mann-Whitney test; $\mathrm{U}=11.000 ; \mathrm{n}=10 ; \mathrm{P}=$ 0.841) and $\mathrm{AH}^{-}$(Mann-Whitney test; $\mathrm{U}=9.000$; $\mathrm{n}=10 ; \mathrm{P}=0.548)$ nor the $\mathrm{A} \cdot$ content $/ \mathrm{AH}^{-}$content ratio in gills (Mann-Whitney test; $\mathrm{U}=11.000$; $n$ $=10 ; \mathrm{P}=0.841)$ did differ significantly between Varela and Golondrina bays (Fig. 4). Typical EPR spectra of $A$ in the liver are shown in Fig. $5 \mathrm{~A}$. The contents of $\mathrm{A}$ (Mann-Whitney test; $\mathrm{U}$ $=0.000 ; \mathrm{n}=10 ; \mathrm{P}=0.050), \mathrm{AH}^{-}$(Mann-Whitney test; $\mathrm{U}=0.000 ; \mathrm{n}=10 ; \mathrm{P}=0.036)$ and the $\mathrm{A} /$ $\mathrm{AH}^{-}$ratio (Mann-Whitney test; $\mathrm{U}=0.000 ; \mathrm{n}=$ $10 ; \mathrm{P}=0.050$ ) assessed in the liver (Fig. 5B) were significantly different between both sampling sites. Significant higher values of A: content in gills than in liver were measured at Varela (Mann-Whitney test; $\mathrm{U}=1.000 ; \mathrm{n}=10$; $\mathrm{P}=0.016)$ and Golondrina (Mann-Whitney test; $\mathrm{U}=1.000 ; \mathrm{n}=10 ; \mathrm{P}=0.016)$ bays. The $\mathrm{A} \cdot \mathrm{AH}^{-}$

TABLE 2

Antioxidant capacity of $O$. nigricans from the different sampling sites. Data are expressed as mean \pm S.E. for three replicates of each of the five individuals from each sampling site. ND: not determined.

Capacidad antioxidante de $O$. nigricans de los distintos sitios de muestreo. Los datos están expresados como la media \pm EE de tres réplicas para cada uno de los cinco individuos de cada sitio de muestreo. ND: no determinado.

\begin{tabular}{lcccc}
\hline & \multicolumn{2}{c}{ Varela bay } & \multicolumn{2}{c}{ Golondrina bay } \\
\hline & Gills & Liver & Gills & Liver \\
\hline$\alpha$-tocopherol $\left(\mathrm{nmol} \mathrm{mg}^{-1} \mathrm{FW}\right)$ & $3 \pm 1$ & $405 \pm 77$ & $7 \pm 2$ & $194 \pm 49$ \\
$\beta$-carotene $\left(\mathrm{nmol} \mathrm{mg}{ }^{-1} \mathrm{FW}\right)$ & $0.1 \pm 0.05$ & $1.4 \pm 0.3$ & $0.3 \pm 0.06$ & $0.9 \pm 0.3$ \\
CAT $\left(\mathrm{U} \mathrm{mg}^{-1} \mathrm{FW}\right)$ & $\mathrm{ND}$ & $7570 \pm 1368$ & $\mathrm{ND}$ & $3560 \pm 1149$ \\
SOD $\left(\mathrm{U} \mathrm{mg}^{-1} \mathrm{FW}\right)$ & $991 \pm 142$ & $1086 \pm 284$ & $799 \pm 118$ & $605 \pm 65$ \\
\hline
\end{tabular}




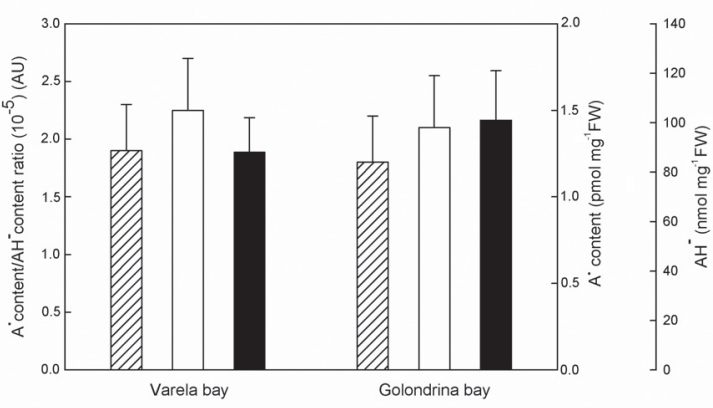

Fig 4: A ( $\square$ ) and $\mathrm{AH}^{-}(\square)$ contents and Acontent $/ \mathrm{AH}^{-}$content ratio $(\square Z)$ ) in gills of $O$. nigricans from different sampling sites.

Contenidos de A ( $\square$ ) y $\mathrm{AH}^{-}(\square)$ y la relación de contenido de $\mathrm{A}$ / contenido de $\mathrm{AH}^{-}(\square Z)$ en branquias de $O$. nigricans capturados en los distintos sitios de muestreo.

ratio was also significantly higher in the gills of fishes from Golondrina bay than in those from Varela bay (Mann-Whitney test; $\mathrm{U}=2.000 ; \mathrm{n}=$ 10; $\mathrm{P}=0.05$; Figs. 4 and $5 \mathrm{~B}$ ).

The contents of GSH, GSSG and the GSH/ GSSG ratio, used as markers of the redox status, are shown in Table 3 . The contents of GSH and GSSG in the liver were $50 \%$ and 86 $\%$ higher at Varela bay respectively, meanwhile the GSH/GSSG ratio was $85 \%$ higher at Golondrina bay (Table 3, Mann-Whitney test; $\mathrm{U}=3.000 ; \mathrm{n}=10 ; \mathrm{P}=0.050)$. No significant differences in the contents of GSH (Golondrina bay: Mann-Whitney test; $\mathrm{U}=7.000 ; \mathrm{n}=10 ; \mathrm{P}=$ 0.309 and Varela bay: Mann-Whitney test; $\mathrm{U}=$ 7.000; $\mathrm{n}=10 ; \mathrm{P}=0.555)$, GSSG (Golondrina bay: Mann-Whitney test; $\mathrm{U}=11.000 ; \mathrm{n}=10 ; \mathrm{P}=0.841$ and Varela bay: Mann-Whitney test; $\mathrm{U}=8.000$; $\mathrm{n}=10 ; \mathrm{P}=0.730)$ and the $\mathrm{GSH} / \mathrm{GSSG}$ ratio (Golondrina bay: Mann-Whitney test; $\mathrm{U}=5.000$; $\mathrm{n}=10 ; \mathrm{P}=0.151$ and Varela bay: Mann-Whitney test; $\mathrm{U}=5.000 ; \mathrm{n}=10 ; \mathrm{P}=0.286$ ) were found between organs at each sampling site.

\section{DISCUSSION}

In the present study, oxidative stress responses in fishes from Golondrina and Varela bays were employed to evaluate the usefulness of a multibiomarker approach in environmental monitoring programs in the Beagle Channel region. Golondrina bay is located near Ushuaia city, the southernmost location on Earth, and has been recently considered by Duarte et al. (2011) as low urban impacted area, despite the
(A)

a

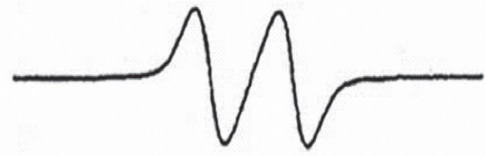

b

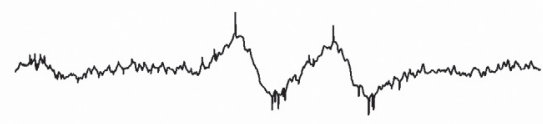

C

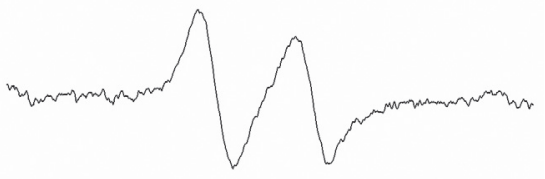

d

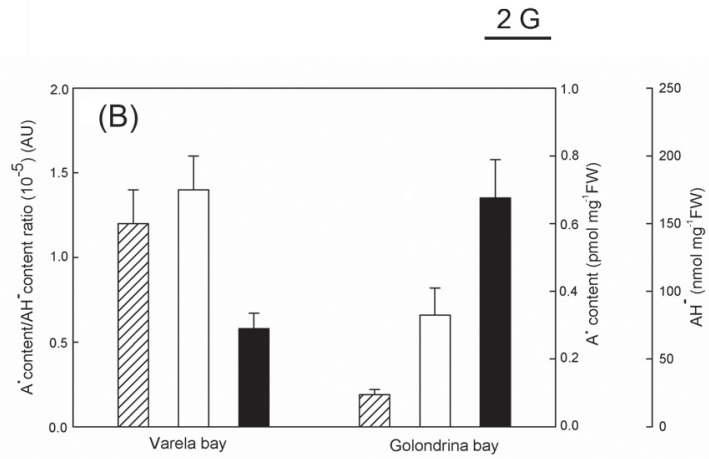

Fig. 5: A: EPR detection of ascorbyl radical in liver of O. nigricans from different sampling sites: (a) computer-simulated EPR spectra employing the following spectral parameters $\mathrm{g}=2.005$ and $\mathrm{a}_{\mathrm{H}}=1.8 \mathrm{G}$, (b) typical EPR spectra from Golondrina bay, (c) typical EPR spectra from Varela bay and (d) EPR spectra of dimethyl sulfoxide (DMSO). B: A' ( $\square$ ) and $\mathrm{AH}^{-}$ ( $)$ contents and $\mathrm{A}^{\cdot} / \mathrm{AH}^{-}$ratio $(\square / Z)$ in liver of $O$. nigricans from different sampling sites.

A: Detección del radical ascorbilo por EPR en el hígado de $O$. nigricans capturados en los distintos sitios de muestreo: (a) espectro de EPR simulado por computadora empleando los siguientes parámetros espectrales $\mathrm{g}=2.005 \mathrm{y} \mathrm{a} \mathrm{H}_{\mathrm{H}}=1.8$ G, (b) espectro típico de EPR para Bahía Golondrina, (c) espectro típico de EPR para Bahía Varela y (d) espectro de EPR de dimetilsulfóxido (DMSO). B: Contenido de A ( $\square$ ) y de $\mathrm{AH}^{-}(\square)$ y relación $\mathrm{A}^{*} / \mathrm{AH}^{-}(\square / \lambda)$ en el hígado de $O$. nigricans de distintos sitios de muestreo.

population's growth around it. Varela bay does not receive anthropogenic inputs, been only visited by local fishermen and tourists during 
TABLE 3

Reduced and oxidized glutathione and GSH / GSSG ratio in the gills and the liver of $O$. nigricans from the different sampling sites. Data are expressed as mean \pm S.E. for three replicates of each of the five individuals from each sampling site.

Glutatión reducido y oxidado y relación contenido de GSH / contenido de GSSG en las branquias y el hígado de $O$. nigricans de los distintos sitios de muestreo. Los datos están expresados como la media \pm EE de tres réplicas para cada uno de los cinco individuos de cada sitio de muestreo.

\begin{tabular}{|c|c|c|c|c|}
\hline & \multicolumn{2}{|c|}{ Varela bay } & \multicolumn{2}{|c|}{ Golondrina bay } \\
\hline & Gills & Liver & Gills & Liver \\
\hline GSH (ng mg-1 FW) & $10 \pm 3$ & $6 \pm 1$ & $6 \pm 4$ & $3 \pm 1$ \\
\hline GSSG (ng mg ${ }^{-1} \mathrm{FW}$ ) & $3 \pm 1$ & $37 \pm 9$ & $3.3 \pm 0.9$ & $5 \pm 2$ \\
\hline GSH/GSSG & $3.8 \pm 0.9$ & $0.2 \pm 0.1$ & $2.5 \pm 0.8$ & $1.3 \pm 0.3$ \\
\hline
\end{tabular}

a short part of the year. In order to assess the link between spatial and temporal changes in quality of coastal waters of the Beagle Channel and antioxidant responses, different works have been previously carried out in native (Duarte et al. 2011, 2012) and transplanted (Giarratano et al. 2010, 2011) mussels Mytilus edulis chilensis (D’Orbigny, 1847) in the Beagle Channel. They found significant differences in oxidative stress responses analyzed in relation to dissolved nutrients in seawater and trace metals in the finest sediment fraction $(<62 \mu \mathrm{m})$. Sediments from Brown bay, which is only $20 \mathrm{~km}$ West of Varela bay, showed higher levels of Fe and $\mathrm{Zn}$ than those from Golondrina bay (Giarratano \& Amin 2010, Duarte et al. 2012). Even though fishermen's activities could be contributing to the trace metal enrichment of sediments from Brown bay, Giarratano \& Amin (2010) believe that most of the concentrations measured derive from the Andean belt itself, since spurts of variable flow reach this coast associated to thawing and drift of materials contributed by Almanza river (Hernando et al. 2008).

The xenobiotics such as metals are known to induce ROS, which are responsible for oxidative stress (Viarengo et al. 1990, Almroth et al. 2005, Gonzalez \& Puntarulo 2011). Assuming that the higher content of $\mathrm{Fe}$ and $\mathrm{Zn}$ found in fine sediments from Brown bay could be similar in Varela bay due the its proximity, these metals could be resuspended in the water column by wave action and/or by physico-chemical changes. That fact could be responsible of the increase of the lipid radical content and the antioxidant activities in the liver, affecting $O$. nigricans from Varela bay through the decrease of the condition factor. However, measurements of trace metals in sediments from Varela bay should be carry out to test this hypothesis.

In several works the $\mathrm{K}$ condition factor has proven to be a useful biomarker to indicate different environmental stress conditions among sites with different characteristics (van der Oost et al. 2003, Linde-Arias et al. 2008). However, this parameter is not sensitive enough to give information of specific responses to the toxic substances in the environment. Presence of contaminants in the environment frequently leads to the depletion of energy reserves as a compensatory mechanism to the higher demand of energy required by detoxification processes (Guerlet et al. 2006). Fishes from Golondrina bay showed $\mathrm{K}$ values significantly higher than those from Varela bay making evident that the former place is a site with less stressful environmental conditions.

The degree of oxidative damage on the fish $O$. nigricans was assessed through the estimation of lipid peroxidation products in the gills and in the liver. Gills were chosen for being the first organ which gets in contact with the environment becoming a potential target for oxidative disruption. Liver was chosen because it possesses high potential for ROS generation, which seems to be efficiently counterbalanced by powerful protective mechanisms to detoxify and repair damaged lipid and proteins (Oliveira et al. 2008, Lattuca et al. 2009, Nahrgang et al. 2010). Endogenous lipid radical products have extremely short half-lives and are present in low concentrations, making difficult their detection. Spin trapping analysis followed 
by EPR overcomes the limit of sensitivity of endogenous radicals in biological systems, and it has proved to be the least ambiguous method to detect short-lived and reactive free radicals generated in low concentrations in biological systems (Luo et al. 2006). Lipid peroxidation has been conveniently used as an effect biomarker by pollution (Ahmad et al. 2008). Particularly, Luo et al. (2006) detected ROS generation induced by 2-chlorophenol in fish Carassius auratus (Linnaeus, 1758) based on the EPR method. Ahmad et al. (2008) observed an increased lipid peroxidation in the gills of the European sea bass Dicentrarchus labrax (Linnaeus, 1758) from a contaminated coastal lagoon in Ria de Aveiro of Portugal. However, lipid radical content neither in gills nor in the liver of $O$. nigricans showed significant differences between Varela and Golondrina bays. The same response was found by Pandey et al. (2003) in the fish Wallago attu (Bloch \& Schneider, 1801) and they argued that induction of antioxidants might have contributed in subsiding the peroxidative effect. It is also possible that this parameter was not sensitive enough to detect differences between the selected areas. Measurement of lipid peroxidation provided no indication of a differential pollution level between sampling sites.

Fishes tend to adapt to oxidative conditions by mobilizing enzymatic as well as nonenzymatic antioxidant defences (Ahmad et al. 2008, van der Oost et al. 2003). SOD and CAT activities, the $\alpha$-tocopherol content and the high $\mathrm{A}^{\bullet} / \mathrm{AH}^{-}$ratio found at Varela bay suggest that the natural environmental stress at this site is higher than at Golondrina bay. The enzymatic antioxidants SOD and CAT provide the first defence against oxygen toxicity. A simultaneous induction of the activities of SOD and CAT has been observed in organisms exposed to pollutants (Dimitrova et al. 1994). In that sense, such relationship found in liver in this study could be attributable to higher natural levels of some trace metals in Varela bay. Jena et al. (2009) proposed the use of ascorbic acid as a biomarker for environmental monitoring. The content of $\mathrm{AH}^{-}$in Golondrina bay was higher than in Varela bay. This may be either due to dietary deficiency or the utilization of ascorbic acid in response to elevated ROS generation (Oakes et al. 2004). The pattern of variation in ascorbic acid content in O.nigricans is comparable to that reported by Jena et al. (2009) for Perna viridis (Linnaeus, 1758) from the coast of India. Further studies would fully describe the use of ascorbic acid as a biomarker for environmental monitoring in the studied areas.

GSH is a co-factor for GPx and GST enzymes and is also an effective protection capable of quenching oxyradicals (Ross 1988). It may be either a result of the novo synthesis as previously demonstrated in fish or a transfer from other organs (Deneke \& Fanburg 1989, Oliveira et al. 2009). An increment of GSH was observed in the liver of fishes from Varela bay, which could be due to the fact that most GSH is synthesized in liver and transported to the bloodstream for supply to other tissues. The same explanation was given by Almroth et al. (2008) for rainbow trout Oncorhynchus mykiss (Walbaum, 1792). Similarly, DiGiulio et al. (1993) observed high levels of GSH in catfish exposed to polluted sediment. The ratio between the reduced GSH and oxidized forms of GSH (GSSG) plays an important role in intercellular signalling and gene regulation (Almroth et al. 2008) and may be a potential biomarker for oxidative stress (van der Oost et al., 2003; Jena et al., 2009). In the current study, the lowest hepatic GSH/GSSG ratio was found at Varela bay indicating a more oxidized redox status. Similar responses of decreased GSH/GSSG ratio have been shown in Perna perna (Linnaeus, 1758) exposed to lead and paraquat (Dafre et al. 2004) and in Mytilus galloprovincialis (Lamarck, 1819) in response to an oil spill in Spain (Sureda et al. 2011).

Taken as a whole, the antioxidant responses were higher in the liver making it an ideal tissue for biomarker studies in O. nigricans. These results are in concordance with those found by Lattuca et al. (2009) who showed that the liver of $O$. nigricans exhibited a better control of the oxidative damage than the gills, allowing minimization of intracellular damage when it is exposed to environmental stressful conditions. The current study indicates that this species also displays an antioxidant response spatially differentiated, in order to counteract pro-oxidant natural factors present in these marine habitats.

We studied silversides from two coastal environments from Beagle Channel and 
we determined the background levels of biochemical parameters that can be considered values of normal homeostasis for wild silversides. The activity of antioxidant defence enzymes investigated in this work should be taken into account in biomonitoring studies with fish species and adequately considered when biomarker responses are interpreted to detect anthropogenic disturbances. Our results support the suitability of employing $O$. nigricans as a sentinel species for assessing the health of coastal areas of the Beagle Channel, as well as in future ecotoxicological field studies.

ACKNOWLEDGEMENTS: This study was supported by grants from the University of Buenos Aires, ANPCyT and CONICET. The authors are grateful to Dr. S. Puntarulo for scientific support and C. Luizon, D. Aureliano and J. Bouzzo for fieldwork and technical assistance.

\section{LITERATURE CITED}

AEBI H (1984) Catalase in vitro. Methods in Enzymology 105: $121-126$.

AHMAD I, VL MARIA, M OLIVEIRA, A SERAFIM, MJ BEBIANNO, M PACHECO \& MA SANTOS (2008) DNA damage and lipid peroxidation vs. protection responses in the gill of Dicentrarchus labrax L. from a contaminated coastal lagoon (Ria de Aveiro, Portugal). Science of the Total Environment 406: 298-307.

ALMROTH BC, J STURVE, A BERGLUND \& L FÖRLIN (2005) Oxidative damage in eelpout (Zoarces viviparous), measured as protein carbonyls and TBARS, as biomarkers. Aquatic Toxicology 73 : 171-180.

ALMROTH BC, E ALBERTSSON, J STURVE \& L FÖRLIN (2008) Oxidative stress, evident in antioxidant defences and damage products, in rainbow trout caged outside a sewage treatment plant. Ecotoxicology and Environmental Safety 70: 370-378.

ALVES DE ALMEIDA E, ACD BAINY, AP DE MELO LOUREIRO, GR MARTINEZ, S MIYAMOTO et al. (2007) Oxidative stress in Perna perna and other bivalves as indicators of environmental stress in the Brazilian marine environment: Antioxidants, lipid peroxidation and DNA damage. Comparative Biochemistry and Physiology Part A 146: 588-600.

BAGENAL TB \& FW TESCH (1978) Methods for assessment of fish production in fresh waters. In: Bagenal TB (ed) Age and growth: 101-136. Blackwell Scientific Publications, Oxford.

BAINY ACD, E SAITO, PSM CARVALHO \& VBC JUNQUEIRA (1996) Oxidative stress in gill, erythrocytes, liver and kidney of Nile tilapia (Oreochromis niloticus) from a polluted site. Aquatic Toxicology 34: 151-162.

BEYER J (1996) Fish biomarkers in marine pollution monitoring; evaluation and validation in laboratory and field studies. PhD thesis, University of Bergen, Norway.
CARRIQUIRIBORDE P \& A RONCO (2002) Sensitivity of the neotropical teleost Odonthestes bonariensis (Pisces, Atherinidae) to chromium (VI), copper (II), and cadmium (II). Bulletin of Environmental Contamination and Toxicology 69: 294-301.

CARRIQUIRIBORDE P \& A RONCO (2008) Distinctive accumulation patterns of $\mathrm{Cd}$ (II), $\mathrm{Cu}$ (II), and $\mathrm{Cr}(\mathrm{VI})$ in tissue of the South American teleost, pejerrey (Odontesthes bonariensis). Aquatic Toxicology 86: 313-323.

DAFRE, AL, ID MEDEIROS, IC MULLER, EC VENTURA \& ACD BAINY (2004) Antioxidant enzymes and thiol/disulfide status in the digestive gland of the brown mussel Perna perna exposed to lead and paraquat. Chemico-Biological Interactions 149: 97-105.

DELEVE LD \& N KAPLOWITZ (1991) Glutathione metabolism and its role in hepatotoxicity. Pharmacology \& Therapeutics 52: 287-305.

DENEKE SM \& BL FANBURG (1989) Regulation of cellular glutathione. American Journal of Physiology 257: 163-173.

DESAI I (1984) Vitamin E analysis methods for animal tissues. Methods in Enzymology 105: 138-146.

DIGIULIO RT, C HABIG, \& EP GALLAGHER (1993) Effects of black river harbour sediments on indices of biotransformation, oxidative stress, and DNA integrity in channel catfish. Aquatic Toxicology 26: 1-22.

DIKOLOVA AE, MB KADIISKA, \& RP MASON (2001) An in vivo EPR spin-trapping study: free radical generation in rats from formate intoxication role of the Fenton reaction. Proceedings of the Natural Academy of Sciences USA 98: 13549-13553.

DIMITROVA MST, V TSINOVA \& V VELCHEVA (1994) Combined effect of zinc and lead on the hepatic superoxide dismutase-catalase system in carp (Cyprinus carpio). Comparative Biochemistry \& Physiology C 108: 43-46.

DUARTE CA, E GIARRATANO, OA AMIN \& LI COMOGLIO (2011) Heavy metal concentrations and biomarkers of oxidative stress in native mussels (Mytilus edulis chilensis) from Beagle Channel coast (Tierra del Fuego, Argentina). Marine Pollution Bulletin 62: 1895-904.

DUARTE CA, E GIARRATANO \& MN GIL (2012) Trace metal content in sediments and autochthonous intertidal organisms from two adjacent bays near Ushuaia, Beagle Channel (Argentina). Marine Environmental Research 79: 55-62.

FORBES VE, A PALMQVIST \& L BACH (2006) The use and misuse of biomarkers in ecotoxicology. Environmental Toxicology and Chemistry 25: 272-280.

GIARRATANO E \& OA AMIN (2010) Heavy metals monitoring in the southernmost mussel farm of the world (Beagle Channel, Argentina). Ecotoxicology and Environmental Safety 73: 1378-1384.

GIARRATANO E, CA DUARTE \& OA AMIN (2010) Biomarkers and heavy metal bioaccumulation in mussels transplanted to coastal waters of the Beagle Channel. Ecotoxicology and Environmental Safety 73: 270-279.

GIARRATANO E, MN GIL, \& G MALANGA (2011) Seasonal and pollution-induced variations in biomarkers of transplanted mussels within the Beagle Channel. Marine Pollution Bulletin 62: 1337-1344. 
GIULIVI C \& E CADENAS (1993) The reaction of ascorbic acid with different heme iron redox states of myoglobin. FEBS Letters 332: 287-290.

GONZALEZ PM \& S PUNTARULO (2011) Iron and nitrosative metabolism in the Antarctic mollusc Laternula elliptica. Comparative Biochemistry and Physiology C 153: 243-250.

GUERLET E，K LEDY \& L GIAMBÉRINI (2006) Field application of a set of cellular biomarkers in the digestive gland of the freshwater snail Radix peregra (Gastropoda, Pulmonata). Aquatic Toxicology 77: 19-32.

HALLIWELL B \& JMC GUTTERIDGE (1999) Free Radicals in Biology and Medicine. Third edition, Oxford University Press, Oxford.

HOLM-HANSEN O \& B RIEMANN (1978) Chlorophyll a determination: Improvements in methodology. Oikos 30: 438-447.

IRAM (2007) Environmental quality. Water quality. Determination of the acute lethal toxicity of substances to freshwater fishes. Semi-static method. Norma IRAM 29112. Institute for Normalization and Certification of Argentina, Buenos Aires, Argentina.

JENA KB, XN VERLECAR \& GBN CHAINY (2009) Application of oxidative stress indices in natural populations of Perna viridis as biomarker of environmental pollution. Marine Pollution Bulletin 58: 107-113.

KOIVULA MJ \& T EEVA (2010) Metal-related oxidative stress in birds. Environmental Pollution 158: 23592370.

KOTAKE Y, T TANIGAWA, M TANIGAWA, I UENO, DR ALLEN \& C LAI (1996) Continuous monitoring of cellular nitric oxide generation by spin trapping with an iron-dithiocarbamate complex. Biochimica et Biophysica Acta 1289: 362-368.

KUTNINK MA, WC HAWKES, EE SCHAUS \& ST OMAYE (1987) An internal standard method for the unattended high-performance liquid chromatographic analysis of ascorbic acid in blood components. Analytical Biochemistry 166: 424-430.

LAI EK, C CROSSLEY, R SRIDHAR, HP MISRA, EG JANZEN \& PB MCCAY (1986) In vivo spin trapping of free radicals generated in brain, spleen, and liver during radiation of mice. Archives of Biochemistry and Biophysics 244: 156-160.

LATTUCA ME, G MALANGA, C AGUILAR HURTADO, AF PÉREZ, J CALVO \& S PUNTARULO (2009) Main features of the oxidative metabolism in gills and liver of Odontesthes nigricans Richardson (Pisces, Atherinopsidae). Comparative Biochemistry and Physiology B 154: 406-411.

LINDE-ARIAS AR, AF INÁCIO, LA NOVO, C DE ALBURQUERQUE \& JC MOREIRA (2008) Multibiomarker approach in fish to assess the impact of pollution in a large Brazilian river, Paraiba do Sul. Environmental Pollution 156: 974979.

LOPEZ-TORRES M, R PEREZ-CAMPO, S CADENAS, C ROJAS \& G BARJA (1993) A comparative research of free radicals in vertebrates - II. Nonenzymatic antioxidants and oxidative stress. Comparative Biochemistry and Physiology B 105: 757-763.

LUO Y, Y SU, R LIN, H SHI \& X WANG (2006) 2-Chlorophenol induced ROS generation in fish
Carassius auratus based on the EPR method. Chemosphere 65: 1064-1073.

MASON RP, PH HANNA, MJ BURKITT \& MB KADIISKA (1994) Detection of oxygen-derived radical in biological systems using electron spin resonance. Environmental Health Perspectives 102: $33-36$

MISRA HP \& I FRIDOVICH (1972) The role of superoxide anion in the autoxidation of epinephrine and simple assay for superoxide dismutase. The Journal of Biological Chemistry 247: 3170-3175.

MOORE MN, MH DEPLEDGE, JW READMEN \& DRP LEONARD (2004) An integrated biomarker-based strategy for ecotoxicological evaluation of risk in environmental management. Mutation Research 552: $247-268$.

NAHRGANG J, L CAMUS, F BROMS, JS CHRISTIANSEN \& H HOP (2010) Seasonal baseline levels of physiological and biochemical parameters in polar cod (Boreogadus saida): Implications for environmental monitoring. Marine Pollution Bulletin 60: 1336-1345.

NATIONAL ADVISORY COMMITTEE FOR LABORATORY ANIMAL RESEARCH (2004) Guidelines on the Care and Use of Animals for Scientific Purposes. NACLAR, Singapore.

OAKES KD, ME MCMASTER \& GJ VAN DER KRAAK (2004) Oxidative stress responses in longnose sucker (Catostomus catostomus) exposed to pulp and paper mill and municipal sewage effluents. Aquatic Toxicology 67: 255-271.

OLIVEIRA M, M PACHECO \& MA SANTOS (2008) Organ specific antioxidant responses in golden grey mullet (Liza aurata) following a short-term exposure to phenanthrene. Science of the Total Environment 396: 70-78.

OLIVEIRA M, VL MARIA, I AHMAD, A SERAFIM, MJ BEBIANNO, M PACHECO \& MA SANTOS (2009) Contamination assessment of a coastal lagoon (Ria de Aveiro, Portugal) using defence and damage biochemical indicators in gill of Liza aurata. An integrated biomarker approach. Environmental Pollution 157: 959-967.

PANDEY S, S PARVEZ, I SAYEED, R HAQUE, B BINHAFEEZ \& S RAISUDDIN (2003) Biomarkers of oxidative stress: a comparative study of river Yamuna fish Wallago attu (B1. \& Schn.). Science of the Total Environment 309: 105-115.

RODRIGUEZ-ARIZA A, F TORIBIO \& J LÓPEZ-BAREA (1994) Rapid determination of glutathione status in fish liver using high-performance liquid chromatography and electrochemical detection. Journal of Chromatography B 656: 311-318.

ROSS D (1988) Glutathione, free radicals and chemotherapeutic agents. Mechanisms of free radical induced toxicity and glutathionedependent protection. Pharmacology \& Therapeutics 37: 231-249.

STEGEMAN JJ, M BROUWER, TDG RICHARD, L FÖRLIN, BA FOWLER, BM SANDERS \& PA VAN VELD (1992) Molecular responses to environmental contamination: Enzyme and protein systems as indicators of chemical exposure and effect. In: Huggett RJ, RA Kimerly, PM Mehrle \& HL Bergman (eds) Biomarkers: biochemical, physiological and histological markers of anthropogenic stress: 235-335. Lewis Publishers, Chelsea, MI, USA. 
SUREDA A, A BOXA, S TEJADA, A BLANCO, J CAIXACH \& S DEUDERO (2011) Biochemical responses of Mytilus galloprovincialis as biomarkers of acute environmental pollution caused by the Don Pedro oil spill (Eivissa Island, Spain). Aquatic Toxicology 101: 540-549.

SWIERGOSZ-KOWALEWSKA R, A BEDNARSKA \& A KAFEL (2006) Glutathion levels and enzyme activity in the issues of bank vole Clethrionomys glareolus chronically exposed to a mixture of metal contaminants. Chemosphere 65: 963-974

VAN DER OOST R, J BEYER \& NPE VERMEULEN (2003) Fish bioaccumulation and biomarkers in environmental risk assessment: A review. Environmental Toxicology and Pharmacology 13: 57-149.

VARANKA $Z$, I ROJIK, I VARANKA, J NEMCSÓK \& M ÁBRAHÁM (2001) Biochemical and morphological changes in carp (Cyprinus carpio L.) liver following exposure to copper sulfate and tannic acid. Comparative Biochemistry and Physiology C 128: 467-477.

Editorial Responsibility: Mauricio Canals

Received March 8, 2013; accepted September 10, 2013
VIARENGO A, L CANESI, M PERTICA, G POLI, MN MOORE \& M ORUNESU (1990) Heavy metal effects on lipid peroxidation in the tissues of Mytilus galloprovincialis lam. Comparative Biochemistry and Physiology C 97: 37-42.

VIARENGO A, D LOWE, C BOLOGNESI, E FABBRI $\&$ A KOEHLER (2007) The use of biomarkers in biomonitoring: A 2-tier approach assessing the level of pollutant-induced stress syndrome in sentinel organisms. Comparative Biochemistry and Physiology C 146: 281-300.

VLAHOGIANNI TH \& A VALAVANIDIS (2007) Heavy-metal effects on lipid peroxidation and antioxidant defence enzymes in mussels Mytilus galloprovincialis. Journal of Chemical Ecology 23: 361-371.

WILSON RP \& WE POE (1973) Impaired collagen formation in the scorbutic channel catfish. Journal of Nutrition 103: 1359-1364.

WINSTON GW \& RT DI GIULIO (1991) Prooxidant and antioxidant mechanisms in aquatic organisms. Aquatic Toxicology 19: 137-161. 